\title{
Salmonella enterica espeziearen andui monofasikoen karakterizazio molekularra eta epidemiologikoa
}

\author{
(Molecular and epidemiological characterization \\ of monophasic variants of Salmonella enterica)
}

Lorena Laorden Muñoz*1, Silvia Herrera-León ${ }^{2}$, Joseba Bikandi Bikandi ${ }^{1}$, Javier Garaizar Candina ${ }^{1}$

${ }^{1}$ Immunologia, Mikrobiologia eta Parasitologia saila, Farmazia Fakultatea, Universidad del País Vasco/Euskal Herriko Unibertsitatea

${ }^{2}$ Enterobakteriak atala, Mikrobiologia Zentru Nazionala, Karlos III. Osasun Institutua, Ekonomia, Industria eta Lehiakortasun Ministerioa

*lorena.laorden@ehu.eus

DOI: $10.1387 /$ ekaia.17892

Jasoa: 2017-05-30

Onartua: 2017-09-27

Laburpena: Salmonelosia, herrialde garatuetako toxiinfekzio ohikoenetariko bat da, Salmonella generoko bakterioek eragindako elikagaien bidezkoa. Salmonella enterica espeziearen barruan 2.500 serotipo baino gehiago deskribatuta daude gaur egun, baina serotipo gutxi batzuk izan dira jarraipen epidemiologiko sakonagoa jaso dutenak. XXI. mendearen lehenengo hamarkadan, biologia molekularreko tekniken aurrerakuntzei esker, Salmonella enterica espeziearen aldaera monofasikoen gehikuntza detektatu zen Espainiako Mikrobiologiako Zentru Nazionalean. Lan honetan, aldaera monofasiko horietako 4 aztertu eta karakterizatu dira tipikazio metodoen bidez. Ondorioz, posible izan da lau aldaeren eboluzio-jatorri zehaztea eta euren detekziorako, jarraipenerako eta kontrolerako diseinatu diren markatzaile epidemiologikoak eskaintzen dira, osasun agintariei epidemiologia esparruan lana erraztearren.

Hitz gakoak: Salmonella enterica, aldaera monofasikoak, insertzio-sekuentziak, bigarren faseko flageloen delezioak, PCR, PFGE, MLVA, genoma osoaren sekuentziazioa (WGS).

Abstract: Salmonellosis, is one of the most common food-poisoning disease caused
by bacteria of the genus Salmonella in developed countries. More than 2,500 serotypes
of Salmonella enterica species are described today, but a few serotypes have been re-
ceived a harbor epidemiological monitoring. On the first decade of the 21 th century,
thanks to advances in molecular biology techniques, the Spanish National Center of 
Lorena Laorden Muñoz, Silvia Herrera-León, Joseba Bikandi Bikandi, Javier Garaizar Candina

Microbiology detected an emergence and increase of monophasic variants of Salmonella enterica. Typification methods allow us the analysis and characterization of 4 monophasic variants. As a result, it has been possible to determine their evolutionary origin and provide epidemiological markers designed for their detection, monitoring and control to facilitate the work in epidemiology of the health authorities.

Keywords: Salmonella enterica, monophasic variants, insertion sequences, second phase flagellar deletions, PCR, PFGE, MLVA, Whole Genome Sequencing (WGS).

\section{SARRERA}

Salmonelosia, Salmonella generoko bakterioek eragindako elikagaien bidezko toxiinfekzio ohikoenetariko bat da herrialde garatuetan.

Salmonelosia, herrialde garatuetako toxiinfekzio ohikoenetariko bat da, Salmonella generoko bakterioek eragindako elikagaien bidezkoa; gastroenteritis akutua da bere manifestazio nagusia [1]. Salmonella enterica espezieak garrantzi epidemiologiko handia du. Osasunaren Mundu Erakundearen (OMS) balioespenaren arabera, urtero milioi bat enterokolitisen eta 400 heriotzen eragilea da, Estatu Batuetan (AEB) [1]. Salmonella enterica XIX. mendetik ezaguna den nonhaiko patogenoa da, eta, gaur egun, 2.500 serotipo baino gehiago deskribatuta daude [2]. Hala ere, serotipo guztiek ez dute garrantzi bera. Izan ere, lagin klinikoetan isolatuak izan dira soilik kontrol eta jarraipen epidemiologiko sakonagoa jaso dituztenak. Salmonella-ren birulentzia oso konplexua da eta ikaragarri aldatzen da serotipoen eta serotipo bereko anduien artean. Salmonella-ren aldakortasun handiak eta aurkezten duen egokitze-gaitasunak ziurtatzen du aukera agetzen denean anduiren bat egotea ostalaria kolonizatzeko [3].

\section{O antigeno somatikoa}

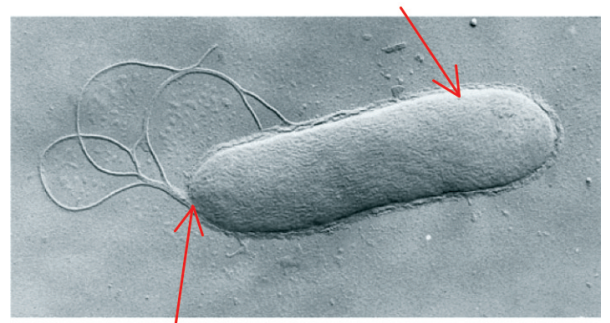

$\mathrm{H}$ antigeno flagelarra

1. irudia. Salmonella enterica bakaterioaren irudi mikroskopikoa. Salmonella-ren O antigeno somatikoaren eta $\mathrm{H}$ antigeno flagelarraren kokapena zehazten da. Vi antigeno kapsularra irudiaren bakterioaren kasuan ez da agertzen. (Creative commons irudia). 
Organismo mota desberdinak espezie baten barruan identifikatzeari tipifikazioa deritzo [4]. Espezie bereko bakterio isolatu batzuen artean bereizten duten tipifikazio-metodoak, funtsezko tresna epidemiologikoak dira prebentziorako eta infekzioaren kontrolerako. Salmonella-ren identifikaziorako, lehenengo isolatzea egin behar da, ondoren karakterizazio biokimikoa, eta, azkenik, serotipifikazioa. Salmonella-ren serotipifikazioa egitura antigenikoan oinarritzen da: $\mathrm{O}$ antigeno somatikoan, $\mathrm{H}$ antigeno flagelarrean eta Vi antigeno kapsularrean (1. irudia). Serotipifikazioak, ahalbidetzen du serotipoak formula antigenikoaren arabera bereiztea. Salmonellaren serotipoen formula antigenikoetan, lehenengo $\mathrm{O}$ antigenoa idazten da, jarraian Vi (baldin badago) eta azkenik $\mathrm{H}$ antigenoak (aurretik 1. fasekoa eta gero 2. fasekoa) (2. irudia).

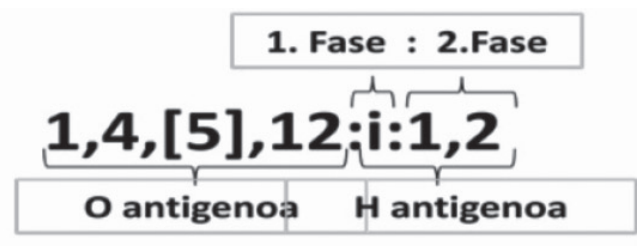

1.fasea 2. fasea

2. irudia. Salmonella enterica Typhimurium serotipoaren formula antigenikoa. Irudian formula antigenikoa idazteko eredua azaltzen da. Kortxeteen artean dauden antigenoak adierazten dute euren presentzia aldakorra dela.

Ikertzaileontzat, antigenoen azterketa egitea serotipoen determinaziorako garrantzitsua izan arren, antigenoen espresioaren aldakortasuna ikertzea ezinbestekoa da. Bakterioen gainazaleko antigenoen espresioaren aldaketa, «Fase-aldaketa» bezala definitzen da. Orokorrean fase-aldaketa delako gertaera itzulezina da eta kanpo faktoreez eragindakoa izan daiteke. Salmo$n e l l a-\mathrm{k} \mathrm{H}$ antigeno flagelarraren fase-aldaketa egiteko gaitasuna dauka. Horrek zenbait ikerlariren hitzetan, eboluzioan abantail bat da ostalariaren defensa-mekanismoak ekiditeko. Fase-aldaketa horren bidez, antigeno flagelar bat adierazten denean $(f l j B)$ beste antigeno flagelarraren errepresioa gertatzen da $(f l i C)$. Lehenengo eta bigarren faseko flageloak kodetzen dituzten geneak $f l i C$ eta $f l j B$ dira hurrenez hurren. Lehenengo edo bigarren faseko flageloaren delezioak eragiten du aldaera monofasikoen agerpena.

Aldaera monofasiko berrien agerpena ez da bakarrik gaur egungoa, baina, gaur egun, eskuragarriak dauden biologia molekularreko erreminta berriek erraztu egin dute aurrez karakterizatu gabe zeuden aldaeren identifikazioa. XXI. mendearen hasieran Espainiako Mikrobiologia Zentru Nazionalean aldaera monofasiko berrien agerpena detektatu zen garrantzi klinikodun laginen artean $[5,6,7]$. 
Lorena Laorden Muñoz, Silvia Herrera-León, Joseba Bikandi Bikandi, Javier Garaizar Candina

Hori kontuan izanda, lan honen oinarria zehaztu zuten Salmonella-k azaltzen duen intzidentziak eta bere detekzioaren, kontrolaren eta kasuen jarraipenaren garrantziak. Doktorego-tesi lan honetan, lau aldaera monofasiko berrien detekziorako ezinbestekoa izan den karakterizazio molekularra egin da eta aldaera horien jarraipen epidemiologikoa egiteko diseinatutako markaitzaile espezifikoak eskaini dira. Azpimarratzekoa da osasun-agintariei informatzeko eta behar diren neurriak hartzeko orduan lortutako datuak eskaintzearen garrantzia.

\section{MATERIALAK, METODOAK ETA EMAITZAK}

Lan honetan 4,[5],12:i:-, 4,5,12:b:- eta 4,12:d:- formula antigenikoekin identifikatutako Salmonella enterica anduien lau bildumak karakterizatu dira, hurrengo biologia molekularreko erreferentzia-teknikak zein tipifikazio teknika berriak erabilita: fagotipifikazioa, antibiograma, PFGE (Pulsedfield gel electrophoresis-PulseNet USA) (3. irudia), MLVA (Multiple-locus variable-number of tandem-repeats analysis) [8, 9] (4. irudia), PCR (Polymerase chain reaction) (5. irudia), PCR produktuen sekuentziazioa eta genoma osoko sekuentziazioa [10] (6. irudia).

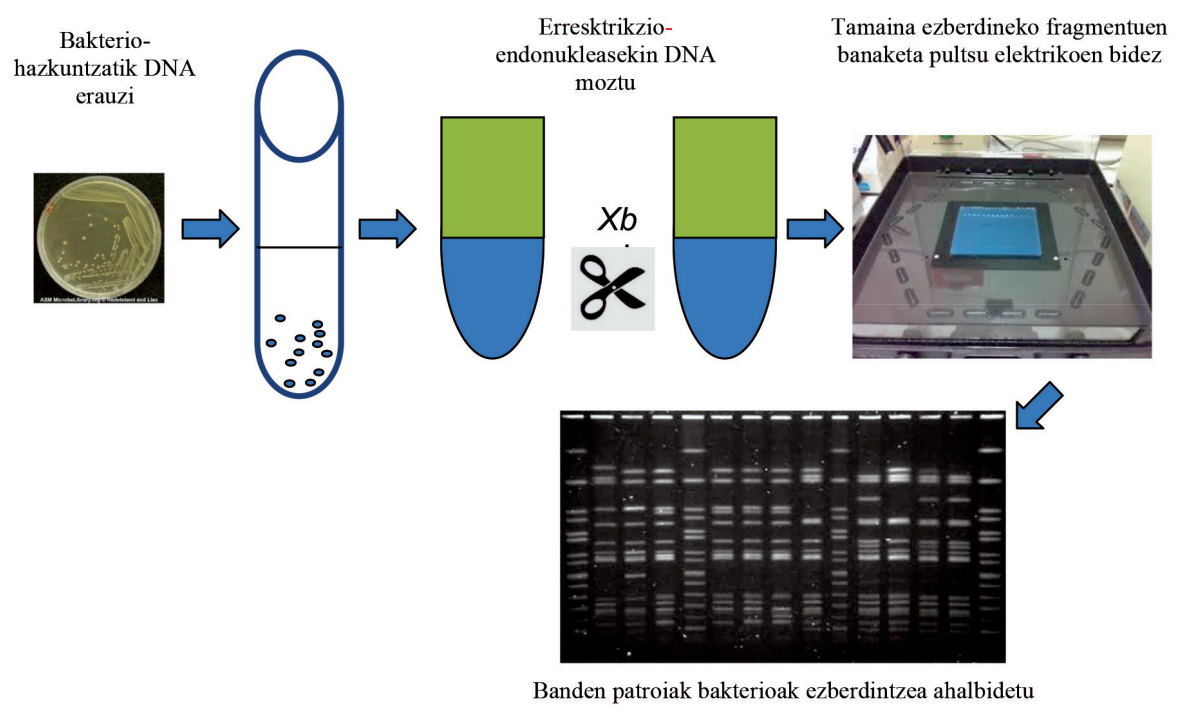

3. irudia. PFGE teknikaren azalpena. 


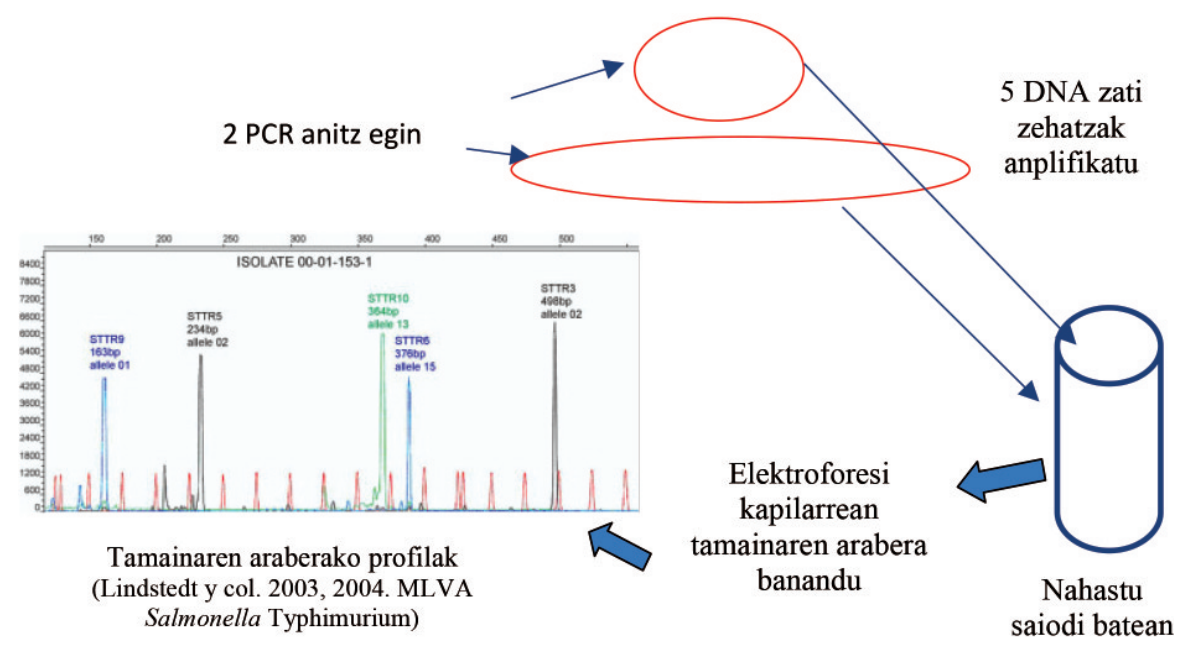

4. irudia. MLVA teknikaren azalpena.

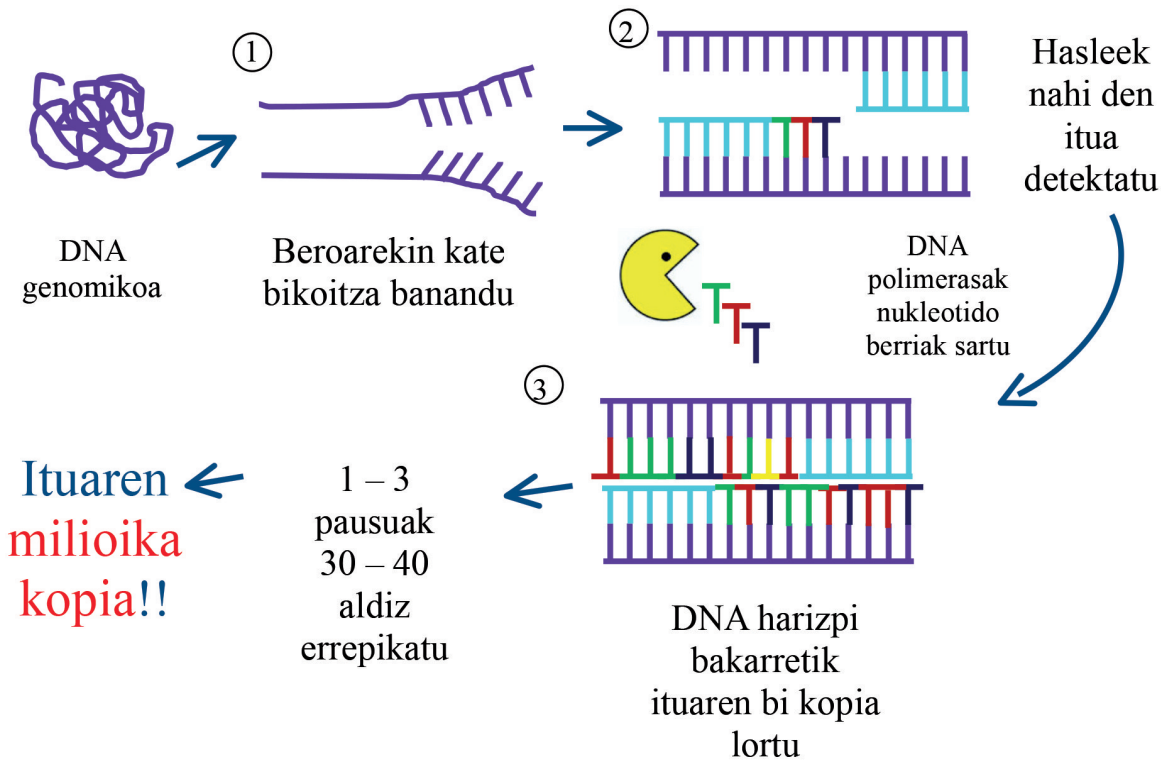

5. irudia. PCR teknikaren azalpena. 
Lorena Laorden Muñoz, Silvia Herrera-León, Joseba Bikandi Bikandi, Javier Garaizar Candina

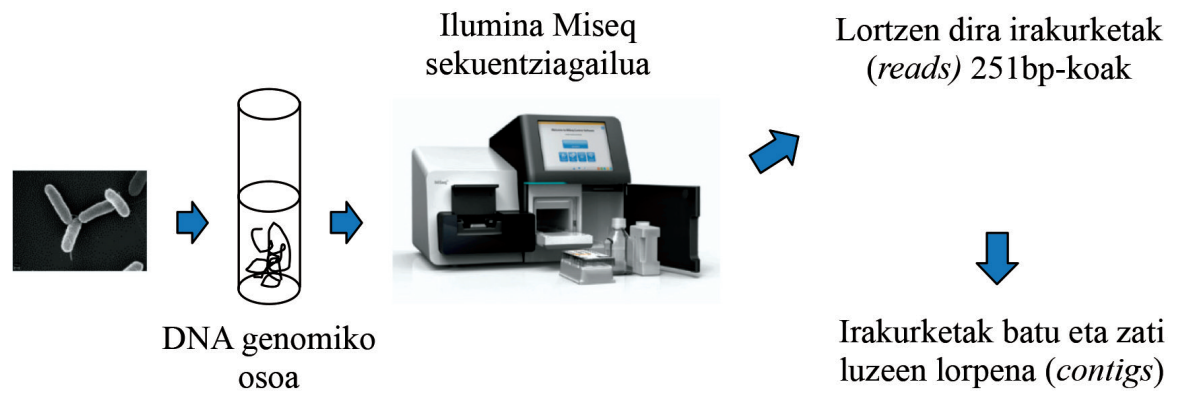

Genoma osoaren sekuentzia

6. irudia. Genoma osoaren sekuentziazio teknikaren azalpena.

Lortutako datuekin, ondorioztatu ahal izan da Salmonella Typhimurium serotipotik datozela 1. eta 2. bildumetako anduiak. Hala ere, haien artean eboluzio-lerro desberdinak bereizten dira.

Lehen bilduma osatzen duten 61 anduiak aztertuta, antzekotasun handia erakusten dutela ikusi dugu, eta beraz, klon bakar bat osatzen dutela ondorioztatu dugu [7].

$S$. Typhimurium serotipoan aurkitutako aldaera monofasikoen artean, lehenengo eboluzio-lerroa osatuko lukete, «klon espainiar» moduan ezaguna dena $[5,15]$. Klon horren ezaugarriak zehaztea posible izan da lan honetan: Salmonella Typhimurium U302 fagotipodun arbasotik dator; arbaso horrek pU302L plasmidoa zuen eta antibiotikoekiko erresistentzia anitzetako profila (R-ACSuGSTSxT: Anpizilina, kloranfenikol, sulfonamida, gentamizina, estreptomizina, tetraziklina eta sulfametoxazol-trimetoprim); klon horren arbasoaren pU302L plasmidoan zegoen IS26 insertzio-sekuentziaren hirugarren kopiak, kromosomaren sekuentzia ezagun bat detektatuta, kromosoman txertatu zen eta andui monofasikoetan dagoen bigarren faseko flageloaren delezioa sortuko zuen; ; ondorioz, lan honetan detektatutako aldaera monofasikoen agerpena eragingo zuen. Bilduma honetako isolatuak aztertuta, flageloaren delezioari dagokionez, 4 delezio mota ezberdin aurkitu dira (7. irudia).

Lau delezio horiek gertatu ahal izateko bi hipotesi plazaratuko ditugu: lehenengo hipotesian, 1. motako delezioa gertatu ondoren (IS26 toki horretan txertatu ondoren), 3 aldaera berri sortuko ziren berrantolaketa genetikoen ondorioz; bigarren hipotesian, IS26-ren insertzioa lau une desberdinetan gertatuko zen eta ondorioz lau delezio mota ezberdin sortuko ziren. Esan beharra dago delezioaren hasiera puntu berean mantentzen dela beti aldaera guztietan. Beraz, IS26-rentzako ezagupen-lekua legoke gune horre- 


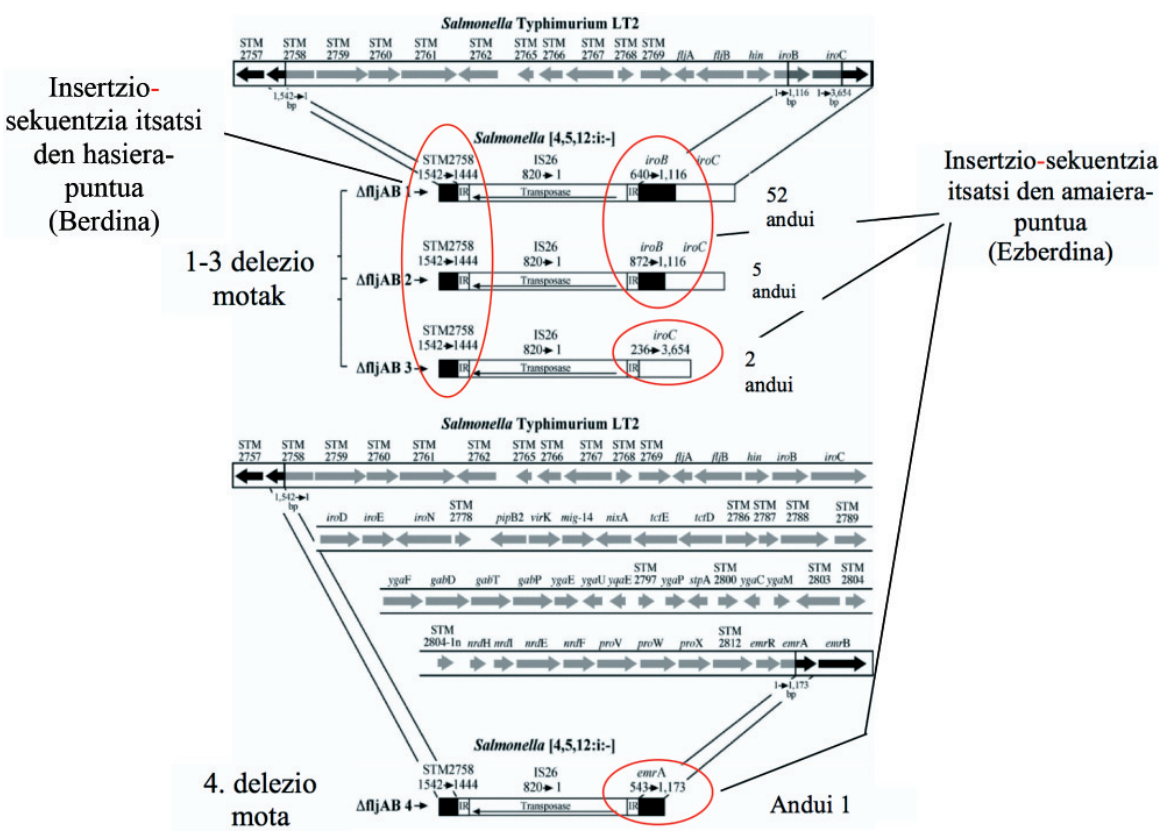

7. irudia. Lehenengo bilduman detektatutako 4 aldaeren delezioak azaltzen dira.

tan. Antzemandako homogeneotasun handiak biltzen dituzte andui horiek klon bereko kide bezala, eta klon espainiarrekoak bezala izendatuko lirateke.

Bigarren bilduman (215 andui) beste bi klon-lerro bereizten dira: amerikarra eta europearra. Bilduma honetako hiru andui Estatu Batuetan deskribatu izan diren anduiekiko oso antzekoak dira. Beraz, andui monofasiko amerikarrarekin arbaso komuna lukete eta, aldi berean, gure herrialdeko gainontzeko anduietatik ezberdina. Bigarren faseko flageloaren delezioa aztertzean, klon amerikarrak azaltzen duen delezio handia erakutsi dute hiru andui hauek eta posible izan da gainontzeko anduietan (212) beste 4 delezio mota txikiago batzuk detektatzea. Bilduma honetan tamaina txikiagoko delezioekin karakterizatu diren gainerako anduien artean ezberdintasunak ere azaltzen dituzte. Bakarrik dira berdinak tetraerresistentzia-profilean eta IS26 sekuentziaren txertaketaren amaiera-puntuan. Beraz, biltzen ditu «klon europar» moduan izendatutako anduien ezaugarri nagusiak. Hala ere PFGE-ak, MLVA-k eta flageloaren delezioaren PCR-ak erakutsitako desberdintasunek adierazten dute aspaldi banandu zirela, arbaso komuna bazuten ere. Bilduma honetan ere hasieran «klon europar» moduan izendatutako hiru andui monofasiko bereizi dira. Hiruretan bigarren faseko flageloaren gabezia antzeman da serotipifikazioa- 
Lorena Laorden Muñoz, Silvia Herrera-León, Joseba Bikandi Bikandi, Javier Garaizar Candina

ren bidez; hala ere, PCRren eta genoma osoaren sekuentziazioaren bidez egiaztatu da $f l j B$ genea mantentzen dutela, baina hainbat IS26 insertzio sekuentziaz zatitua edo inguratuta (bi aukerak azaltzen dituzte). Aurkikuntza honek, hipotesi bat plazaratzeko bidea ireki du: hiru andui berezi hauek 2. bildumaren aldaera Europearren jatorrizko arbasoa edo arbasoaren antzekoak izan litezke.

Lan honen hirugarren bilduman bildu ditugu detektatu berri ditugun Salmonella enterica espeziearen 4,5,12:b:- serotipoaren anduiak. Beste bildumekin jarraitutako tipifikazio-teknikak erabiliz, 40 andui karakterizatuta haien jatorria zehaztu dugu: Salmonella Paratyphi B serotipoko eta tartratoa metabolizatzeko $(\mathrm{dT}+)$ gai den hirugarren klon-lerrotik datozen aldaera monofasikoak lirateke eta antibiotikoekiko erresistentziarik gabekoak. Dena den, salbuespen bat dago: tartratoa metabolizatzeko gaitasuna ez duen andui bakarra, (dT-) Salmonella Paratyphi B dT negatibotik etorriko litzatekeena, eta, beraz, arbaso ezberdinekoa. Delezioa isolatu gehienetan karakterizatu arren, ez da datu nahikorik lortu delezioaren atzean dagoen gertaera genetikoa ezagutzeko. Isolatuen gehiengoak $f l j B$ genearen alboko 27 generen delezioa aurkezten dute.

Delezioa transposasa batek eragingo zuen, baina geroago transposasak bere egituraren zati bat galduko zuen eta ondorioz, 281 bp-eko zati erabilezina utziko zuen, andui hauen kromosoman txertatuta. PFGE teknikak, aldaera honetako anduien arteko aniztasun handia erakusten du. Izan ere, 4 banda-profila edo 4 pultsotipo ezberdin (A-B-C-D) identifikatu dira bertan. Esan beharra dago A pultsotipoko anduiek erakusten dutela homologia handiena, eta, hain zuzen ere, haiek direla lan honetan deskribatutako delezioa aurkeztu dutenak. Beste hiru pultsotipoen artean biltzen dira karakterizatu gabeko delezioa zuten 10 anduik. Ondorioztatzen dugu, beraz, 10 andui horiek eboluzio-lerro ezberdinetakoak izan daitezkeela, eta, ondorioz, bigarren faseko flageloaren sintesian parte hartzen duten geneen delezio mota desberdinak dituztela.

Laugarren bilduman Salmonella enterica espezieko 4,12:d:- serotipoko anduiak sailkatu ditugu (19 andui). Ikerketa lan honetan zehaztu ahal izan dugu Salmonella Schwarzengrund-etik datozen aldaera monofasikoak direla eta oso homogeneoak direnez, klon bera osa lezaketela. Behaketek erakutsi dute 11 generen delezioa jasan dutela, eta, gene horien artean, bigarren faseko flageloaren sintesian parte hartzen duten geneak daudela. Delezioa IS30 insertzio-sekuentzia batek sortua litzateke. Aldaera honek homogeneotasun handia erakutsi du PFGE teknikaren bidez, zein antibiograma-datuetan, eta, bai karakterizatutako delezio motan ere. Beste aldetik, IS30a txertatu den amaiera puntua bat dator $S$. Typhimurium serotipoaren klon europarraren anduietan deskribatutako nukleotido berarekin. 
Salmonella enterica espeziearen andui monofasikoen karakterizazio molekularra eta epidemiologikoa

\section{ONDORIOAK}

Ikerketa lan honetan egindako karakterizazio eta tipifikazio prozeduren ostean anduiak lau bilduma ezberdinetan antolatu ahal izan dira, euren ezaugarrien eta zehaztutako eboluzio-jatorriaren arabera. Lehenengo eta bigarren bildumak (4,[5],12:i:- formula antigenikodunak) gure herrialdean diren Typhimurium serotipoko bi aldaera monofasikoak osatzen dute.

Hirugarren eta laugarren bildumetan garrantzi klinikoa duten baina Typhimurium serotipoarenak ez diren bi aldaera monofasikoak karakterizatu dira, 4,5,12:b:- eta 4,12:d:- formula antigenikodunak. Emaitza guztiak aztertuta, posible izan da doktorego-tesi honen hasierako helburuak betetzea: Isolamenduen karakterizazioa, anduien ustezko eboluzio-jatorria identifikatzea eta ikerkuntza-proiektu egitasmo honetan zehar sortu eta erabilitako markatzaile epidemiologikoak diseinatzea eta eskaintzea, aldaera monofasiko berri hauen detekziorako, kontrolerako eta jarraipenaren hobekuntzarako.

Lan honetan karakterizatutako aldaeren agerpena eta jatorria eboluzioaren ondorio izan da. Berezko mutazioak, hautespen naturala eta isolamenduak, eboluzio biologikoaren funtsezko elementuak dira eta elementu genetiko mugikorren transposizioaz eragindakoa izan daiteke $[11,12]$.

Elementu genetiko transposagarriak edo transposonak 70. hamarkadan aurkitu ziren eta IS1 izan zen Escherichia coli-n identifikatutako lehenengo insertzio-sekuentzia (IS). Insertzio-sekuentziak bakterioen kromosomaren edo plasmidoen osagai arrunt bezala agertzen dira (Normalean IS-ek lehentasuna erakusten dute DNAko eskualde jakin batuetan txertatzeko) [13, 14]. Txertatzeak iradokitzen du IS-en muturrak zenbait itu-sekuentzia ezagutu ditzaketela kromosoman zeharreko txertatze-prozesuan. Insertzio-sekuentziak, luzeerari dagokionez nahiko motzak dira eta gainera, nahiko trinkoak. Mugikortasun funtzioa besterik ez dute kodetzen. Horregaitik IS-en egiturak bere mugikortasunerako ezaugarri garrantzitsu bat adierazi behar du. Mutur bakoitzeko, nukleotidoen sekuentzia, ITR edo Mutur errepikakor alderantzikatuaz osatuta dago (Inverted Terminal Repeats). ITR horiek ezinbesteko osagaiak dira IS-a DNAn txertatzeko mekanismoetan [14]. Insertzio-sekuentziak hoberen definitzen duen zatia transposasa da (bere kokapena kodetzen duen entzima). Normalean bat edo bi genez kodetuta dago eta IS-aren gehiengoa osatzen dute. Hortaz, insertzio-sekuentziak DNAren zati txiki bezala definitzen dira $(<2.5 \mathrm{~kb})$, antolaketa genetiko sinplea eta itu-molekularen toki anitzetan txertatzeko gaitasuna dutelarik [13] (8. irudia).

Lan honen ondorio bezala baiezta dezakegu bigarren faseko flageloaren sintesiaren zonaldea puntu aktiboa dela insertzio-sekuentzien edo transposonen txertaketarako, eta Salmonella enterica espeziearen anduietan bigarren faseko flageloaren sintesi-ahalmenean eragiten duela. Hala ere, flagelo 
Lorena Laorden Muñoz, Silvia Herrera-León, Joseba Bikandi Bikandi, Javier Garaizar Candina

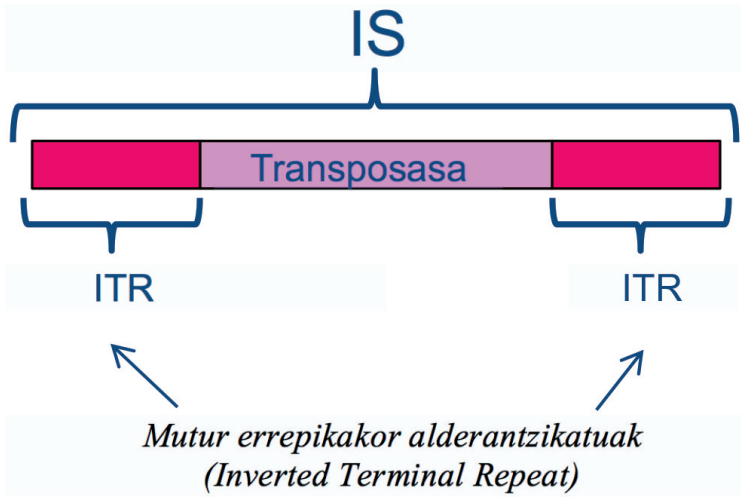

8. irudia. Insertzio-sekuentzia baten egitura orokorra.

baten galera ez da eboluzio-desabantaila izan andui monofasiko hauentzat, gure estatuan lagin klinikoetan 4. serotipo ohikoena izatera heldu baitzen XXI. mendearen hasieran.

Arber zientzialari ospetsu eta nobel saridunaren hitzetan, berezko mutazioak, hautespena eta isolamendua funtsezkoak dira eboluzio biologikoan. Aldatzeko eta bere ingurunerako era eraginkorragoan moldatzeko gai den organismoa da eboluzio-abantaila lortuko dituena eta horrek bere espeziearen biziraupenari lagunduko dio $[11,12]$. Bibliografian, Salmonellaren flageloei buruzko iritzi ezberdinak aurki daitezke: batzuek pentsatzen dute antigenoen adierazpena aldatzeko ahalmenak aukera ematen duela ostalariaren immunitate-erantzuna saihestu ahal izateko; beste batzuek aldiz ukatu egiten dute hipotesi hori [16]. Doktorego-tesi honen anduien karakterizazio lana kontuan izanda, ondorioztatzen dugu-flageloen fase-aldaketa ez dela eboluzio-abantaila Salmonella-rentzat, ikerketa honetan aztertutako 4 aldaeren eboluzio-arrakasta ikusita. Andui monofasiko hauek ezin dute fase-aldaketarik egin eta horrek ez du eragozpenik ekarri, hazteko, sakabanatzeko eta gizakiak erasotzeko unean.

\section{BIBLIOGRAFIA}

[1] SCALLAN E., HOEKSTRA R.M., ANGULO F.J., TAUXE R.V., WIDDOWSON M.A., ROY S.L., JONES J.L. eta GRIFFIN P.M.. 2011. «Foodborne illness acquired in the United States-major pathogens». Emerging Infectious Diseases Journal. 17: 7-15.

[2] GRIMONT P.A.D. eta WEILL F.X. 2007. «Antigenic formulae of the Salmonella serovars. $9^{\text {th }}$ edition. WHO Collaborating Centre for Reference and Research on Salmonella». Institut Pasteur, Paris, France. 
Salmonella enterica espeziearen andui monofasikoen karakterizazio molekularra eta epidemiologikoa

[3] ANDREOLETTI O., BUDKA H., BUNCIC S., COLLINS J. D., GRIFFIN J., HALD T., HAVELAAR A., HOPE J., KLEIN G., MCLAUCHLIN J., MÜLLER-GRAF C., NGUYEN-THE C., NOERRUNG B., PEIXE L., PRIETO MARADONA M., RICCI A., SOFOS J., THRELFALL J., VÅGSHOLM I. eta VANOPDENBOSCH E. 2010. «Scientific Opinion on monitoring and assessment of the public health risk of «Salmonella Typhimurium-like» strains». EFSA Journal. 8: 1826.

[4] SABAT A. J., BUDIMIR A., NASHEV D., SÁ-LEAO R., VAN DIJL J.M., LAURENT F., GRUNDMANN H. eta FRIEDRICH A.W. 2013. «Overview of molecular typing methods for outbreak detection and epidemiological surveillance». Eurosurveillance. 18: 20380.

[5] ECHEITA M.A., HERRERA S., eta USERA M.A.. 2001. «Atypical, fljBnegative Salmonella enterica subsp. enterica strain of serovar 4,5,12:i:- appears to be a monophasic variant of serovar Typhimurium». Journal of Clinical Microbiology. 39. 2981-2983.

[6] GARAIZAR, J., PORWOLLIK S., ECHEITA A., REMENTERIA A., HERRERA S., WONG R. M-Y., FRYE J., USERA M.A., eta MCCLELLAND M. 2002. «DNA microarray-based typing of an atypical monophasic Salmonella enterica serovar». Journal of Clinical Microbiology. 40: 20742078.

[7] LAORDEN L, HERRERA-LEÓN S, MARTÍNEZ I, SANCHEZ A, KROMIDAS L, BIKANDI J, REMENTERIA A, ECHEITA A. eta GARAIZAR J. 2010. «Genetic evolution of the Spanish multidrug-resistant Salmonella enterica 4,5,12:i:- monophasic variant». Journal of Clinical Microbiology. 48: 4563-6.

[8] LINDSTEDT B.A., VARDUND T., AAS L. eta KAPPERUD G. 2004. «Multiple-locus variable-number tandem-repeats analysis of Salmonella enterica subsp. enterica serovar Typhimurium using PCR multiplexing and multicolour capillary electrophoresis». Journal of Microbiological Methods. 59: $163-172$.

[9] LINDSTEDT B.A., HEIR E., GJERNES, E. eta KAPPERUD, G. 2003. «DNA fingerprinting of Salmonella enterica subsp. enterica serovar Typhimurium with emphasis on phage type DT104 based on variable number of tandem repeat loci». Journal of Clinical Microbiology. 41: 1469-1479.

[10] DIDELOT X., BOWDEN R., WILSON D., PETO T. eta CROOK D. 2012. «Transforming clinical microbiology with bacterial genome sequencing». Nature Reviews Genetics. 13: 601-612.

[11] ARBER W. 1990. «Mechanisms in microbial evolution». Journal of Structural Biology. 104: 107-11. Review.

[12] ARBER W. 1991. «Elements in microbial evolution». Journal of Molecular Evolution. 33: 4-12. Review.

[13] IIDA S., MEYER J. eta ARBER W. 1981. «Genesis and natural history of IS-mediated transposons». Cold Spring Harbor Symposia on Quantitative Biology Journal. 45: 27-43. 
Lorena Laorden Muñoz, Silvia Herrera-León, Joseba Bikandi Bikandi, Javier Garaizar Candina

[14] MOLLET B., IIDA S., SHEPHERD J. eta ARBER W. 1983. «Nucleotide sequence of IS26, a new prokaryotic mobile genetic element». Nucleic Acids Research Journal. 11: 6319-6330.

[15] ECHEITA M.A., ALADUEÑA A., CRUCHAGA S., eta USERA M.A. 1999. «Emergence and spread of an atypical Salmonella enterica subsp. enterica serotype 4,5,12:i:- strain in Spain Journal of Clinical Microbiology. 37: 3425 .

[16] BÄUMLER A.J., TSOLIS R.M., FICHT T.A. eta ADAMS L.G. 1998. «Evolution of host adaptation in Salmonella enterica». Infection and Immunity. 66: 4579-87. Review. 